\title{
Implementing Immediate Feedback with Unlimited Plus Bonus Points to Increase College Student Learning Motivation and Achievement
}

\author{
Riyanto \\ Prof., Faculty of Teacher Training and Education, Bengkulu University, Indonesia, \\ riyanto@unib.ac.id
}

\section{Diah Aryulina}

Ph.D., Retired from Faculty of Teacher Training and Education, Bengkulu University, Indonesia,aryulina_d@yahoo.com

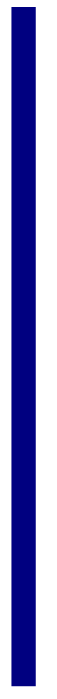

In this study, immediate feedback, revision opportunities, and bonuses with three levels of appreciation were implemented gradually following the challenges of improving the instruction of the Education Statistics course. The research objectives at the end of the series of improvement actions were: 1) whether the implementation of immediate feedback with unlimited plus bonus points (IFUPBP) can increase learning motivation, and 2) whether the implementation of immediate feedback with unlimited plus bonus points (IFUPBP) can increase learning achievement. This study was an action research with the time-series design of different subject groups. The participants were first semester students of the Education Technology Master Program of Teacher Training and Education Faculty at Bengkulu University, from class VIII to XII who attended the Education Statistics course. Learning motivation was measured through the number of bonus points earned by the students and the number of students who earned bonus points on each homework and exam. Learning achievement was measured using an essay test. Learning motivation and achievement data were analyzed descriptively. The results of the study showed that the implementation of immediate feedback with unlimited plus bonus points (IFUPBP) can increase student learning motivation and achievement in the Education Statistics course at Bengkulu University.

Keywords: Immediate feedback, bonus points, learning motivation, learning achievement, college students

\section{INTRODUCTION}

One of the main goals of higher education in Indonesia is to develop the potential of students to become independent lifelong learners (Kemenkumham, 2012). The ability to learn independently needs to be trained through learning habits. Semester Credit System

Citation: Riyanto, \& Aryulina, D. (2020). Implementing Immediate Feedback with Unlimited Plus Bonus Points to Increase College Student Learning Motivation and Achievement. International Journal of Instruction, 13(3), 387-400. https://doi.org/10.29333/iji.2020.13327a 
applied in Indonesian higher education since 1979 is designed to encourage students to develop study habits, not only during lectures but also outside of the lecture (Universitas Bengkulu, 2017; Kemendiknas, 2013). In the Semester Credit System, one semester credit unit is equivalent to 50 minutes of attending lecture, 60 minutes of doing structured assignments, and 60 minutes of independent learning for 16 sessions (University of Bengkulu, 2017; Ministry of National Education, 2013) or a minimum of 16 sessions (Kemenristekdikti, 2015). However, in practice, many students have not studied according to the terms of the semester credit system. The result of an interview at the beginning of each lecture to undergraduate and graduate students of the Education Department at Bengkulu University showed that approximately $80 \%$ of students study outside the classroom for only one hour per day. There are one or two students who study more than two hours per day, one or two students who study more than five hours per day, and the rest study less than one hour per day. Most students study if there is homework. If undergraduate students take 22 credits they should be required to study outside the classroom for 8.8 hours per day for five working days or 7.3 hours for six working days.

Learning habits of students are encouraged through structured learning outside the classroom by giving homework (Universitas Bengkulu, 2017). In addition to developing learning habits, homework plays an important role in strengthening learning. Eliminating homework means reducing the opportunity for students to learn material outside the classroom, therefore reducing their academic achievement. The positive influence of doing homework on learning outcomes is indicated for example by research from Pebriana et al., (2018) and Young et al. (2016).

Homework as part of lecture assignments can be formative and summative assessments (Yorke, 2003). The assignment becomes formative assessment if it is only for assessing the learning process but simultaneously becomes a summative assessment if its grade can contribute to the course grade. Yorke further emphasized that assignment as formative assessments need to be strengthened by providing feedback. Hattie \& Timperley (2007) defines feedback as information provided by an agent regarding aspects of one's performance or understanding. They said that the feedback given by someone outside themselves, for example from lecturers to students, as external feedback. Further, they explained that feedback can be task feedback, task process feedback, student self-regulation feedback, or feedback about the student themselves. Feedback on tasks that only provide information about the accuracy of the answers is classified as task feedback.

The main purpose of feedback is to reduce the gap between students' understanding and skills with the learning objectives (Hattie \& Timperley, 2007). Students who actively take advantage of feedback in their learning produce better learning achievements and self-regulation (Brown et al., 2016). Effect of feedback on increasing learning outcomes compared to non-feedback is also shown by Darwis (2017) and Osuala et al. (2018). Núñez-Peña et al. (2015) found a positive correlation between feedback and learning outcomes, and the possibility of the role of feedback on reducing math learning anxiety. Improving learning outcomes is inseparable from learning motivation that is enhanced by feedback (Hattie \& Timperley, 2007). This is supported by findings from 
Burkšaitienė (2012), Pitt \& Norton (2017), Ghilay \& Ghilay (2015), and Nahadi et al. (2015). According to students, they are motivated because feedback can help them focus on learning to overcome difficulties, and they also feel their learning progress is noticed by the lecturer (Ghilay \& Ghilay, 2015). Brown et al. (2016) also expressed students' opinions that homework feedback increases their self-confidence and helps them to know what is not yet understood.

One characteristic of effective feedback for the adult learner is given immediately (Thurlings et al., 2013). This opinion is supported by the findings of Kehrer et al. (2013) and Seruni \& Hikmah (2014) which revealed that better learning outcomes in students who obtain immediate feedback than delayed feedback on their homework. Different results are shown by Badyal et al. (2019) and Delucenay et al. (2017) who found that immediate feedback does not affect learning outcomes. However, they both found that students preferred immediate feedback. Even according to Fook \& Nazamud-din (2017), students consider the task more useful if given immediate feedback. Immediate feedback makes a better learning process and deeper lesson understanding (Badyal et al., 2019). Similar findings were also revealed by Garner et al. (2013), which also shows that immediate feedback develops positive academic relationships between students and the lecturer. This is supported by Mullet et al. (2014) who found (2014) that students who receive delayed feedback feel disconnected. Another related role of immediate feedback is to increase learning motivation (Farmani et al., 2017; Koen et al., 2012). Farmani et al. (2017) proved that the motivation of language learners who are given immediate feedback is higher than those who are given delayed feedback. According to Koen et al. (2012), immediate feedback is useful in guiding students' learning while still focusing on a topic. Motivation in the form of higher interest towards Basic Statistics lessons on students who were given immediate feedback is indicated by research conducted by Seruni \& Hikmah (2014).

Another characteristic of effective feedback based on cognitive learning theory is elaborative, which involves students actively correcting their mistakes (Thurlings et al., 2013). Improvements to mistakes based on feedback can be encouraged by allowing revising the assignment (Riddel, 2015; Stellmack et al., 2012). They found that the opportunity to revise the assignment can improve learning achievement in writing. According to Cross et al. (2016), reflection on what has been learned that arises when revising tasks is positively correlated with test readiness. In other words, revisions provide a chance for students to reflect which then contributes to improving learning achievement. The opportunity to revise tasks for better achievement can motivate students (Ackerman et al., 2017). Feedback for revision contains information that helps students improve tasks. Conversely, if students are not allowed to revise, their motivation to use feedback is weak (Dysthe, 2011). Dysthe found that the same problem in academic writing reappeared repeatedly if students were not allowed to revise after being given feedback.

The elaborative features of effective feedback (Thurlings et al., 2013) can also be developed by awarding bonus points (Heikkinen, 2014; Pandey, 2015). Awarding bonus points increases student learning motivation (Ingalls, 2018; Jovanovic \& Matejevic, 2014; Pandey, 2015) and achievements (Artés \& Rahona, 2013; Heikkinen, 2014; 
Ingalls, 2018; and Planchard et al., 2015). Jovanovic \& Matejevic (2014) argued that appreciation from the lecturer is not harmful to the students as the opinion of some researchers because of the award as an external motivator associated with motivation to do the task. Pandey (2015) also found that feedback and appreciation developed feelings of empowerment that strengthened intrinsic motivation. Research by Planchard et al. (2015) showed that giving a bonus or an extra bonus did not significantly increase student learning motivation as measured in the number of tasks completed. However, it was found that according to students, having bonuses or extra bonuses was better than without bonuses.

In this study, immediate feedback, the opportunity to revise, and bonus with three levels of awards were implemented gradually following the challenge of instruction improvement on the Education Statistics course as an effort to improve student learning motivation and achievement. The purpose of this study which was a series of improvement actions is to find 1) whether the implementation of immediate feedback with unlimited plus bonus points (IFUPBP) can increase learning motivation, and 2) whether the immediate feedback with unlimited plus bonus points (IFUPBP) can increase learning achievement.

\section{METHOD}

\section{Research Design}

This research is action research in the Education Statistics course in the Education Technology Master Program of Teacher Training and Education Faculty at Bengkulu University, which was conducted from 2012 to 2017. According to Johnson \& Christensen (2014), action research focuses on efforts to solve local problems by practitioners or communities through the implementation of new strategies. The implementation of a new strategy or action is then examined for its influence (Anderson \& Herr, 2013). The strategy which was combined gradually to increase student learning motivation and achievement in this study is the provision of immediate feedback, the opportunity to revise, and the appreciation with three-level bonuses on homework, midterm exam, and final exam.

The implementation of this strategy was based on the reflection of the Education Statistics instruction on students of class VII to XI. Reflection of instruction is a stepping stage for carrying out a plan of action then implementing and observing actions in each cycle of improvement (Johnson \& Christensen, 2014).

The research design was a time series of different subject groups. This research design is a modification of an interrupted time-series design that is classified in a quasiexperiment (Johnson \& Christensen, 2014). A quasi-experimental design can be applied to action research (Anderson \& Herr, 2013; Johnson \& Christensen, 2014). In the interrupted time-series design, there is only one group of participants, whereas in this study there were five groups of students from different classes which was given different learning strategies. The research design used also did not apply pretest for each group, so only the posttest series in the form of weekly homework, midterm exam, and final exam. Different learning strategy in each group was determined based on reflection on the instruction of Education Statistics course in the previous group to improve 
instructional strategy as the core of action research. The time-series design of different subject groups in this study is shown in Table 1. The instructional strategies applied to each student group are described in the following narration.

Table 1

Time Series Design of Different Subject Groups

\begin{tabular}{|c|c|c|c|c|c|c|c|c|c|}
\hline Action & Multiple & Action & Multiple & Action & Multiple & Action & Multiple & Action & Multiple \\
\hline I & Posttests & II & Posttests & III & Posttests & IV & Posttests & V & Posttests \\
\hline $\mathrm{X}_{\mathrm{I}}$ & $\frac{Y_{1.1}-Y_{1 . n}}{Y_{2.1}-Y_{2 . n}}$ & $\mathrm{X}_{\mathrm{II}}$ & $\frac{Y_{1.1}-Y_{1 . n}}{Y_{2.1}-Y_{2 . n}}$ & $\mathrm{X}_{\mathrm{III}}$ & $\begin{array}{l}Y_{1.1}-Y_{1 . n} \\
Y_{2.1}-Y_{2 . n}\end{array}$ & $\mathrm{X}_{\mathrm{IV}}$ & $\begin{array}{l}Y_{1.1}-Y_{1 . n} \\
Y_{2.1}-Y_{2 . n}\end{array}$ & $\mathrm{X}_{\mathrm{V}}$ & $\begin{array}{l}Y_{1.1}-Y_{1 . n} \\
Y_{2.1}-Y_{2 . n}\end{array}$ \\
\hline
\end{tabular}

$\mathrm{X}_{1}=$ immediate feedback

$\mathrm{X}_{2}=$ immediate feedback, revision

$\mathrm{X}_{3}=$ immediate feedback, revision, limited bonus points

$\mathrm{X}_{4}=$ immediate feedback, revision, unlimited bonus points

$\mathrm{X}_{5}=$ immediate feedback, revision, unlimited plus bonus points

$\mathrm{Y}_{1}=$ learning motivation

$\mathrm{Y}_{2}$, = learning achievement

For students of class VIII and before, learning motivation was encouraged through learning habits by giving homework every week. Homework was corrected with feedback and returned immediately to students. Students who were late in submitting homework were scored 0 , and for students whose scores did not achieve 70 (minimal score of mastery learning) were not given a chance to revise. This strategy has the disadvantage that students lack motivation to learn if they have been late in submitting homework or have received low scores. Also, a low average score of homework can reduce the course's final grade.

Based on experience in action I, students of class IX who were late in submitting homework were allowed to submit it in the following week, but with a maximum score of 60. Also, students who had not been completed could revise their assignments and be given a maximum score of 70 . This strategy increased student motivation and did not cause jealousy for students who were on time in submitting homework and who got high grades. However, in this strategy, most students were still working on a given task. In fact, for those students who get high scores, they should be able to do more on a given task.

The next strategy improvement in the students of class $\mathrm{X}$ was to apply limited bonus points for students who do more on the given task. This limited bonus points strategy was combined with previous improvement actions which were immediate feedback and an opportunity to revise. In a limited bonus points strategy, if they do all the tasks correctly and exceed the given task, they get a value of $100+, 100++$, or $100+++$. For example, if there is a minimum assignment of 4 problems, and the students work on 5 problems but the correct one is only 4, then they get a score of 100. If students work on 5 problems and correct, then they get a score of 100+. If students work on 6 questions and correct, then they get a score of $100++$. The highest bonus is +++ (three plus). The weakness in this strategy is that the bonus is not used to increase the score of homework. Bonuses were also not given to mid-term exam and final exam.

Further, the improvement action on the student of class XI was immediate feedback with unlimited bonus points. The bonus points were given to students who work more on an 
unlimited number of problems in homework and exams. Besides, one bonus point is equaled to the score corresponding to the difficulty level of the problem. Excess bonus points on homework can only be transferred to other homework.

In the class XII students, immediate feedback with unlimited bonus points plus was applied as the fifth teaching improvement action. Excess bonus points on the final score of homework can be transferred to the score of midterm and final exams. The number of bonus points from additional problems done by students and the number of students who work more each time doing homework and exam are indicators of learning motivation.

\section{Participant}

Participants of this study were first semester students of the Education Technology Master Program, Faculty of Teacher Training and Education, Bengkulu University, class VIII to XII who attended the Education Statistics course. The number of students in each class was as follows: 27 students of class VIII in the 2012/2013 academic year, 35 students of class IX in the 2013/2014 academic year, 30 students of class X in the $2014 / 2015$ academic year, 18 students of class XI in the 2015/2016 academic year, and 19 students of class XII in the 2016/2017 academic year. Educational and occupational background of the participants was quite diverse. Some of them were educators such as kindergarten teachers, elementary school teachers, junior high school teachers, senior high school teachers, lecturers, while others were not educators. All students taking the Education Statistics course were taught by the researcher. Thus the research participants were determined non-randomly by convenience participants (Johnson \& Christensen, 2014).

\section{Data Collection}

The data collected in this study were learning motivation and learning achievement. Measurement of student learning motivation refers to the opinion of Touré-Tillery \& Fishbach (2014) that motivation can be measured through behavioral indicators to achieve a goal which includes a choice of actions and performance namely accuracy, number, and level of achievement. Measurement of motivation through action choices in this study was the number of students who choose to do more problems and earned bonus points, while measurement through performance was the number of bonus points earned by the students on each homework and exam.

Learning achievement was measured using essay tests (Groundlund \& Linn, 1990). The test covered cognitive domains on aspects of understanding, application, analysis, and evaluation. The test items were developed based on the basic competency goals and competency standards to be achieved in the Education Statistics course. Tests were given in the form of homework and during midterm exams and a final exam. Score weight of test answer was equated to homework, midterms, and final semester examinations. The score per item test is 10 if the student's answer is correct and 0 if it is wrong or not done.

\section{Data Analysis}

The data on student learning motivation and achievement in each class were analyzed descriptively. Descriptive analysis was chosen because the results of the study were not to be generalized beyond the participants studied (Johnson \& Christensen, 2014). The 
technique of learning motivation data analysis used was the average bonus of homework, midterm exam, final exam, and the combination. The average combined bonus point from each student class was then compared with each other. Data on the learning achievement of each student class were analyzed by 1) the percentage of the score categories of homework, midterm exam, final exam, and the combination, and 2) the average score of the combined homework, midterm exam, and final exam score. Percentage of learning achievement score categories and average learning achievement scores of each student class then compared with each other.

\section{FINDINGS}

The influence of immediate feedback with unlimited plus bonus points on learning motivation

A descriptive analysis of student learning motivation in the Educational Statistics course is shown in Table 2. In the second improvement action which was providing immediate feedback with the opportunity for revision, there was no increase in student learning motivation compared to the first action which was providing immediate feedback without opportunity for revision. This second action had not implemented a bonus appreciation for students who work on additional problems from the problems given. Student learning motivation in both actions is categorized fair. Learning motivation of students in action $\mathrm{V}(=10,45)$ is much better than those in action IV $(=1,26)$ and action III $(=0,14)$. The category of learning motivation in action III is high, in action IV is very high, and action V is excellent. In each action III, IV, and V learning motivation when doing homework is higher than when doing midterm and final exams. Learning motivation when doing homework is the highest in action V ( $=20,84$, category $=$ excellent). In this action $\mathrm{V}$, the strategy of immediate feedback and unlimited plus bonus points was implemented on homework, midterm exam, and final exam.

Table 2

Average Learning Motivation based on the Number of Bonus Points

\begin{tabular}{|c|c|c|c|c|c|c|c|c|c|c|c|c|c|c|c|}
\hline \multirow[t]{2}{*}{ Action } & \multicolumn{3}{|c|}{ I } & \multicolumn{3}{|c|}{ II } & \multicolumn{3}{|c|}{ III } & \multicolumn{3}{|c|}{ IV } & \multicolumn{3}{|c|}{$\mathrm{V}$} \\
\hline & $\overline{\mathrm{HW}}$ & $\mathrm{ME}$ & $\mathrm{FE}$ & HW & $\mathrm{ME}$ & FE & HW & $\mathrm{ME}$ & $\mathrm{FE}$ & HW & $\mathrm{ME}$ & FE & HW & $\mathrm{ME}$ & $\mathrm{FE}$ \\
\hline Bonus & 0 & 0 & 0 & 0 & 0 & 0 & 92 & 1 & 0 & 454 & 11 & 8 & 3956 & 26 & 174 \\
\hline Mean & 0 & 0 & 0 & 0 & 0 & 0 & 0,39 & 0,03 & 0 & 2,67 & 0,65 & 0,47 & $\begin{array}{c}20,8 \\
4\end{array}$ & 1,37 & 9,15 \\
\hline $\begin{array}{l}\text { Overall } \\
\text { Mean }\end{array}$ & & 0 & & & 0 & & & 0,14 & & & 1,26 & & & 10,45 & \\
\hline
\end{tabular}

Mean
$\mathrm{HW}=$ Homework
$\mathrm{ME}=$ Midterm exam
$\mathrm{FE}=$ Final exam

The number of students who worked more on homework, midterms and semester final exams fluctuated in actions III, IV, and V (Figure 1). The number of students who works on additional problems in action $\mathrm{V}$ is more than those in action IV, as well as those in action IV, are more than those in action III. In action III, 23 of the 30 students had worked more. In action IV, all 17 students had worked more, even though only one student worked more on each homework, midterm, and final exam. Similar results as in action IV also occur in action V. All 19 students worked more, while those who worked 
more on each homework, midterm and final exam were only two students. Fluctuations in the number of students working on additional problems are more likely due to the difficulty of the homework and exam problem or inappropriate study habits. In this study, it was also found that students were more diligent and disciplined to study outside the classroom which was indicated by the orderliness of students submitting homework. Even students who were absent in lecture sessions still submit assignments through their friends. This also shows an increase in student learning motivation.
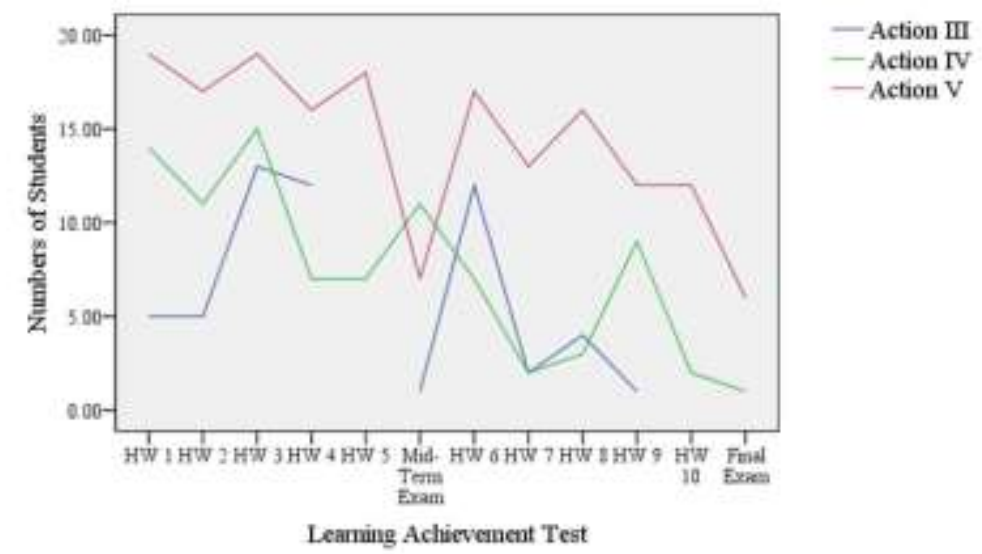

Figure 1

Number of Students who Work More on Problems

The influence of immediate feedback with unlimited plus bonus points on learning achievement

Based on the average learning achievement as presented in Table 3, student learning achievement increases in each improvement action in the Education Statistics course. Student learning achievement in action II $(=79,9)$ is higher than in action I $(=76,1)$. Learning achievement in action III $(=83,03)$ increased in action IV $(=90,69)$ then increased again in action V $(=108)$. From the category of student learning achievement in homework and midterm exam, there is also an increase in its proportion from action I to action $\mathrm{V}$.

Table 3

Proportion of Categories and Mean of Learning Achievement

\begin{tabular}{|c|c|c|c|c|c|c|c|c|c|c|c|c|c|c|c|}
\hline \multirow{2}{*}{$\begin{array}{l}\text { Action } \\
\text { Grade }\end{array}$} & \multicolumn{3}{|c|}{$\mathrm{I}(\%)$} & \multicolumn{3}{|c|}{ II $(\%)$} & \multicolumn{3}{|c|}{ III (\%) } & \multicolumn{3}{|c|}{ IV $(\%)$} & \multicolumn{3}{|c|}{$\mathrm{V}(\%)$} \\
\hline & $\mathrm{HW}$ & $\mathrm{ME}$ & $\mathrm{FE}$ & $\mathrm{HW}$ & ME & $\mathrm{FE}$ & HW & $\mathrm{ME}$ & $\mathrm{FE}$ & HW & ME & $\mathrm{FE}$ & HW & $\mathrm{ME}$ & $\mathrm{FE}$ \\
\hline $\mathrm{A}$ & 85 & 44 & 0 & 94 & 29 & 68 & 90 & 60 & 57 & 100 & 59 & 76 & 100 & 63 & 52 \\
\hline $\mathrm{B}$ & 15 & 41 & 19 & 6 & 38 & 17 & 10 & 23 & 13 & & 41 & 24 & & 37 & 16 \\
\hline $\mathrm{C}$ & & 15 & 55 & & 18 & 6 & & 17 & 7 & & & & & & 32 \\
\hline $\mathrm{D}$ & & & 26 & & 9 & 6 & & & 13 & & & & & & \\
\hline$E$ & & & & & 6 & 3 & & & 10 & & & & & & \\
\hline Mean & & 76,1 & & & 79,9 & & & 83,05 & & & 90,69 & & & 108 & \\
\hline
\end{tabular}

$\mathrm{HW}=$ Homework

$\mathrm{ME}=$ Midterm exam

$\mathrm{FE}=$ Final exam 
In action $\mathrm{V}$, students who get an $\mathrm{A}$ grade on learning achievement on homework are $100 \%$ and on midterm are $63 \%$, while on the final exam does not show an increase in action $\mathrm{V}$ compared to the previous actions. But overall, the number of students whose learning achievement grade is $\mathrm{A}$ is the most in action $\mathrm{V}$ (Figure 2). But overall, the highest number of students who get A on learning achievement is in action V (Figure 2). Students who obtained an A learning achievement as much as $90 \%$ on the action V, $76 \%$ in the action IV, and $67 \%$ in the action III. Thus, the instruction improvement action through the application of immediate feedback with unlimited plus bonus points can increase student learning achievement.

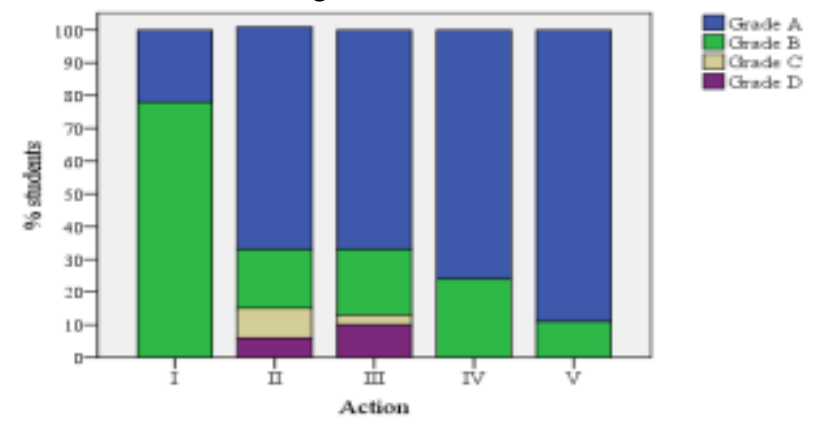

Figure 2

Proportion of the Grade of Student Learning Achievement in Each Action

\section{DISCUSSION}

\section{The influence of immediate feedback with unlimited plus bonus points on learning motivation}

The results of this study indicate that the implementation of immediate feedback with unlimited plus bonus points can increase learning motivation. In this fifth improvement action, student learning motivation in the Education Statistics course is much higher than in the previous actions. Immediate feedback affects learning motivation (Farmani et al., 2017; Koen et al., 2012). According to Farmani et al. (2017), the motivation of language learners who were given immediate feedback is higher than those given delayed feedback. Immediate feedback is useful to guide students while still focusing on learning on a topic (Koen et al., 2012). Motivation in the form of higher interest in the Basic Statistics course is shown by students who were provided immediate feedback on their homework (Seruni \& Hikmah, 2014). The importance of giving feedback to improve learning motivation is also shown by Burkšaitiene (2012), Pitt \& Norton (2017)., Ghilay \& Ghilay (2015), and Nahadi et al. (2015). Feedback is an important aspect of learning because it increases motivation to reduce the gap between what students understand and what they should understand (Hattie \& Timperley, 2007). Ghilay \& Ghilay (2015) revealed that students are motivated because they can focus on learning to overcome their difficulties, and they also feel that their learning development is considered by the lecturer. 
In this study, the opportunity to revise homework after being given immediate feedback that was implemented in the second improvement action also seems to contribute to increasing student learning motivation. This result is following survey research by Ackerman et al. (2017) which shows that students are more motivated if they are allowed to use feedback to revise their assignments for a better score. Feedback can contain information that helps students improve their next assignment. Students' low motivation to utilize feedback if not allowed revision is revealed in a qualitative case study by Dysthe (2011). The results of his research show that the same problem in academic writing reappears repeatedly if students are not allowed to make revisions after being given feedback.

Providing bonuses that started on the third improvement action of this study can also contribute to increasing student learning motivation. The results of this study are in line with research by Ingalls (2018), Jovanovic \& Matejevic (2014), and Pandey (2015). Some researchers agree that the award from lecturers is not dangerous for students because the award as an external motivator is related to the motivation to do the task (Jovanovic \& Matejevic, 2014). Pandey (2015) also found that feedback and appreciation developed feelings of empowerment which strengthened intrinsic motivation. Research by Planchard et al. (2015) showed different results. In their research, giving bonuses or extra bonuses did not significantly increase student learning motivation as measured in the number of tasks completed. Their elaborative finding using questionnaires indicates that bonuses or extra bonuses are not enough to encourage student motivation because other factors are quite influential such as tasks that are considered by students to be too difficult or take a long time to complete. However, it was revealed that to motivate students, giving bonuses and extra bonuses was better than without bonuses. This self-report study from Planchard et al. (2015) explained the findings of this study, that not all students work more problems even though they will be given bonuses or extra bonuses.

The influence of immediate feedback with unlimited plus bonus points on learning achievement

The results of this study indicate that the implementation of immediate feedback with unlimited plus bonus points can improve learning achievement. Similar to the findings on learning motivation, student achievement in the Statistics Education course is much higher in the fifth instruction improvement action compared to the previous actions. Immediate feedback in this study can improve learning achievement. This finding is in line with previous research from Kehrer et al. (2013) and Seruni \& Hikmah (2014) which also indicate that learning outcomes are better for students who obtain immediate feedback than delayed homework. Different results are shown by Badyal et al. (2019) and Delucenay et al. (2017) who found no effect of immediate feedback on student learning outcomes. However, they both found that students preferred immediate feedback. Fook \& Nazamud-din (2017) research also revealed that students considered the task to be more useful if feedback is given immediately. According to students, immediate feedback makes a better learning process and deeper material understanding (Badyal et al., 2019). Apart from being given immediately or delayed, feedback 
improves learning outcomes rather than non-feedback (Dervish, 2017; Osuala et al., 2018). Brown et al. (2016) found that students who actively take advantage of feedback in their learning produce better learning achievement and self-regulation. Núñez-Peña et al. (2015) also found a positive correlation between feedback and learning outcomes, and the possibility of its role in reducing mathematics learning anxiety.

In this study, instruction improvement in the form of the opportunity to revise tasks that began in the second action can play a role in increasing learning achievement. This finding supports Riddel's (2015) and Stellmack et al. (2012) research which were conducted on students in writing learning. Cross et al. (2016) revealed that reflection on what has been learned that arises when making task revisions is positively correlated with test readiness. In other words, revisions provide opportunities for students to reflect which can then play a role in improving learning achievement.

Giving bonuses to the third to fifth instruction improvement actions can also contribute to increasing student learning achievement. This finding supports the research of Artés \& Rahona (2013), Heikkinen (2014), Ingalls (2018), and Planchard et al. (2015). The strategy of giving bonuses is relatively more advantageous for academically low students (Artés \& Rahona, 2013). Providing bonus points is considered by students as an opportunity to increase lecture grades, also helps improve understanding of the material needed for the exam (Ingalls, 2018). Students try to study harder to get extra bonuses (Heikkinen, 2014). The greater the bonus might make students work harder so that their learning achievement is higher. The findings of this study show a much higher learning achievement in students who were given unlimited plus bonus points on homework, i.e. excess bonuses can be added to the exam scores.

\section{CONCLUSION}

Implementation of immediate feedback with unlimited plus bonus points can increase student learning motivation and achievement. The increase in student learning motivation and achievement is gradually following the application of a combination of instruction improvement action that is immediate feedback, opportunity for revision, limited bonus points, unlimited bonus points, and unlimited plus bonus points. This instruction improvement action requires considerable effort and time from the lecturer, but the effort is effectively applied to the condition of students who have relatively low motivation to learn. Based on the findings of this study, giving feedback should be required by lecturers on assignments and examinations. Practices that make feedback more effective for student learning as given immediately, revision opportunity based on feedback, and given appropriate bonuses can be applied following the conditions of student motivation level.

This action research has limitations. The research was carried out in a small scope and was limited to graduate students in the Education Statistics course taught by the researcher. Each instruction improvement action of five actions was applied to different classes with a different number of students and different times according to the instruction series from 2012 to 2017. Nevertheless, this study is following the 
characteristics of action research conducted continuously through a reflection-actionplanning process to improve instruction as part of lecturer professionalism.

\section{REFERENCES}

Ackerman, D. S., Dommeyer, C. J., \& Gross, B. L. (2017). The effects of source, revision possibility, and amount of feedback on marketing students' impressions of feedback on an assignment. Journal of Marketing Education, 39(1), 17-29. https://doi.org/10.1177/0273475316628293.

Anderson, G. L., \& Herr, K. 2013. Practitioner action research and educational leadership. In S. Noffke, \& B. Somekh (Eds.), The sage handbook of educational action research (pp.155 - 165). London: SAGE Publications Ltd.

Artés, J., \& Rahona, M. (2013). Experimental evidence on the effect of grading incentives on student learning in Spain. The Journal of Economic Education, 44(1), 3246. http://dx.doi.org/10.1080/00220485.2013. 740387.

Badyal, D. K., Bala, S., Singh, T., \& Gulrez, G. (2019). Impact of immediate feedback on the learning of medical students in pharmacology. Journal of Advances in Medical Education, 7(1),1-6.

Brown, G. T., Peterson, E. R., \& Yao, E. S. (2016). Student conceptions of feedback: Impact on self-regulation, self-efficacy, and academic achievement. British Journal of Educational Psychology, 86(4), 606-629. https://doi.org/10.1111/bjep.12126.

Burkšaitienè, N. (2012). Promoting student learning through feedback in higher education. Socialiniu Mokslu Studijos Societal Studies, 4(1), 33-46.

Cross, S., Denise, W., \& Jenna, M. (2016). Does the quality and quantity of exam revision impact on student satisfaction and performance in the exam itself? Perspectives from undergraduate distance learners. EDULEARN16 Proceedings, IATED Academy, 5052-5061. https://doi.org/10.21125/edulearn.2016.2197.

Darwis, R. H. (2017). Efektivitas pemberian tes formatif dengan umpan balik terhadap hasil belajar statistik deskriptif. Histogram: Jurnal Pendidikan Matematika, 1(1), 43-50.

Delucenay, A. J., Conn, K. M., \& Corigliano, A. (2017). An evaluation of the impact of immediate compared to delayed feedback on the development of counseling skills in pharmacy students. Pharmacy Education, 17(1), 322-328.

Dysthe, O. (2011). What is the purpose of feedback when revision is not expected? A case study of feedback quality and study design in a first-year master's programme. Journal of Academic Writing, 1(1), 135-142.

Farmani, R., Akbari, O., \& Ghanizadeh, A. (2017). The impact of immediate and delayed error correction on Iranian EFL learner's motivation. European Journal of Foreign Language Teaching, 2(3), 76-88.

Fook, C. Y., \& Nazamud-din, A. (2017). Strategies to enhance assignment and feedback practices in the 21 st century classroom: A case study. Pertanika J. Soc. Sci. \& Hum., 25, 155-166. 
Garner, S. M., Gusberg R. J., \& Kim, A. W. (2013). The positive effect of immediate feedback on medical student education during the surgical clerkship. Journal of Surgical Education, 71(3), 392-397. https://doi.org/10.1016/j.jsurg.2013.10.009.

Ghilay, Y., \& Ghilay, R. (2015). FBL: Feedback based learning in higher education. Higher Education Studies, 5(5), 1-10.

Groundlund, E. F., \& Linn, R. L. 1990. Measurement and evaluation in teaching. New York: Macmillan.

Hattie, J., \& Timperley, H. (2007). The power of feedback. Review of Educational Research, 77(1), 81-112. https://doi.org/10.3102/003465430298487.

Heikkinen, S. (2014). Effects of extra marks in course evaluation in engineering education. Journal of Teaching and Education, 3(3), 131-135.

Ingalls, V. (2018). Incentivizing with bonus in a college statistics course. REDIMAT, 7(1), 93-103. http://dx.doi.org/10.17583/redimat.2018.2497.

Johnson, R. B., \& Christensen, L. (2014). Educational research: Quantitative, qualitative, and mixed approaches. Thousand Oaks, CA: SAGE Publications.

Jovanovic, D., \& Matejevic, M. (2014). Relationship between rewards and intrinsic motivation for learning - researches review. Procedia - Social and Behavioral Sciences, 149, 456-460. https://doi.org/10.1016/j.sbspro.2014.08.287.

Kehrer, P., Kelly, K., \& Heffernan, N. (2013). Does immediate feedback while doing homework improve learning? Proceedings of the Twenty-Sixth International Florida Artificial Intelligence Research Society Conference, 542-545. Association for the Advancement of Artificial Intelligence (www.aaai.org).

Kemendiknas. (2013). Statuta Universitas Bengkulu. Jakarta: Kemendiknas.

Kemenkumham. (2012). Undang-Undang Republik Indonesia Nomor 12 Tahun 2012 tentang Pendidikan Tinggi [Salinan]. Jakarta: Kemenkumham. Retrieved from https://www.kopertis4.or.id/download/undang-undang-republik-indonesia-nomor-12tahun-2012-tentang-pendidikan-tinggi/.

Kemenristekdikti. (2015). Permenristekdikti nomor 44 Tahun 2015 tentang Standar Nasional Perguruan Tinggi [Salinan]. Jakarta: Kemenristekdikti. Retrived from https://lddikti13.ristekdikti.go.id/2016/01/26/standar-nasional-pendidikan-tinggi-tahun$2015 /$.

Koen, M., Bitzer, E. M., \& Beets, P. A. D. (2012). Feedback or feed-forward? A case study in one higher education classroom. J Soc Sci, 32(2), 231-242. https://doi.org/10. 1080/09718923.2012.1189306.

Mullet, H. G., Butler, A. C., Verdin, B., Borris, R., \& Marsh, E. J. (2014). Delaying feedback promotes transfer of knowledge despite student preferences to receive feedback immediately. Journal of Applied Research in Memory and Cognition, 3, 222 229. https://doi.org/10.1016/j.jarmac.2014.05.001.

Nahadi, H. F., \& Farina, J. (2015). Effect of feedback in formative assessment in the student learning activities on chemical course to the formation of habits of mind. Jurnal Pendidikan IPA Indonesia, 4(1), 36-42. https://doi.org/10.15294/jpii.v4i1.3499. 
Núñez-Peña, M. I., Bono, R., \& Suárez-Pellicioni, M. (2015). Feedback on students' performance: a possible way of reducing the negative effect of math anxiety in higher education. International Journal of Educational Research, 70, 80-87. https://doi.org/ 10.1016/j.ijer.2015.02.005.

Osuala R. C., Onwuagboke, B. B. C., \& Agoha T. C. (2018). Continuous assessment feedback and students' performances in semester examinations in a college of education. American Journal of Educational Research, 6(6), 688-693.

Pandey, H. M. (2015). Reward feedback and success for inspiring creative Minds: An inspirational model. J of Eng Edu Tr, S.Is., 47-51. doi: 10.16920/jeet/2015/v0i0/59454.

Pebriana, I. N., Sutopo, \& Diantoro, M. (2018). Dampak program resitasi terhadap pemahaman konsep mahasiswa pada topik fluida dinamis. Jurnal Pendidikan: Teori, Penelitian, dan Pengembangan, 3(8), 1110-1114.

Pitt.E, \& Norton, N. (2017). 'Now that's the feedback I want!' Students' reactions to feedback on graded work and what they do with it. Assessment and Evaluation in Higher Education, 41, 499-516. https://doi.org/10.1080/02602938.2016.1142500.

Planchard, M., Daniel, K. L., Maroo, J., Mishra, C., \& McLean, T. (2015). Homework, motivation, and academic achievement in a college genetics course. Bioscene, 4l(2), 1118.

Riddel, J. (2015). Performance, feedback, and revision: Metacognitive approaches to undergraduate essay writing. Collected Essays on Learning and Teaching, VIII, 79-95. https://doi.org/10.22329/celt.v8i0.4256.

Seruni, \& Hikmah, N. (2014). Pemberian umpan balik dalam meningkatkan hasil belajar dan minat belajar mahasiswa. Jurnal Formatif, 4(3), 227-236.http://dx.doi.org/10.309 98/ formatif.v4i3.158.

Stellmack, M. A., Keenan, N. K., Sandidge, R. R., Sippl, A. L., \& Konheim-Kalkstein, Y. L. (2012). Review, revise, and resubmit: The effects of self-critique, peer review, and instructor feedback on student writing. Teaching of Psychology, 39, 235-244. https://doi.org/10.1177/00986283124565.

Thurlings, M., Vermeulen, M., Bastiaens, T., \& Stijnen, S. (2013). Understanding feedback: A learning theory perspective. Educational Research Review, 9, 1-15. https: //dx.doi.org/10.1016/j.edurev.2012.11.004.

Touré-Tillery, M. \& Fishbach, A. (2014). How to measure motivation: A Guide for the experimental social psychologist. Social and Personality Psychology Compass, 8(7), 328-34. https://doi.org/10.1111/spc3.12110.

Universitas Bengkulu. (2017). Panduan Akademik Tahun 2017. Bengkulu: U Bengkulu. Yorke, M. (2003). Formative assessment in higher education: Moves towards theory and the enhancement of pedagogic practice. Higher Education, 45, 477-501. https://doi.org/ 10.1023/A:1023967026413.

Young. N., Dollman, A., \& Angel, N. F. (2016). Does homework really matter for college students in quantitatively-based courses? J of Lear in Hig Edu, 12(1), 19-26. 